\title{
Foreign Bribery Enforcement
}

What Happens to the Public Officials on the Receiving End? 



\section{Foreign Bribery Enforcement: What Happens to the Public Officials on the Receiving End?}


OECD (2018), Foreign Bribery Enforcement: What Happens to the Public Officials on the Receiving End? www.oecd.org/corruption/foreign-bribery-enforcement-what-happens-to-the-public-officials-on-the-receiving-end.htm

This work is published under the responsibility of the Secretary-General of the OECD. The opinions expressed and arguments employed herein do not necessarily reflect the official views of the OECD, the governments of OECD member countries, or Parties to the Convention on Combating Bribery of Foreign Public Officials in International Business Transactions.

This document and any map included herein are without prejudice to the status or sovereignty over any territory, to the delimitation of international frontiers and boundaries and to the name of any territory, city, or area. 


\section{Foreword}

The Convention on Combating Bribery of Foreign Public Officials in International Business Transactions (the Anti-Bribery Convention) is the foremost global legal instrument for fighting the supply side of foreign bribery. The supply side of foreign bribery relates to what bribers do - it involves offering, promising or giving a bribe to a foreign public official to obtain an improper advantage in international business. In contrast, the demand side of foreign bribery refers to the offence committed by public officials who are bribed by foreign persons.

This study explores whether there is a "flip side" to enforcement actions that ended in sanctions for the supply-side of a foreign bribery transaction. It focuses on what happened on the receiving end of this transaction. That is to say, were the public officials in the demand-side country also sanctioned or otherwise disciplined?

The findings are based a survey of Parties to the Anti-Bribery Convention. In the survey, 20 countries received a total of 55 questionnaires about their demand-side actions for a sample of cases in which sanctions were imposed for a supply-side offence by another Party to the Anti-Bribery Convention between 2008 and 2013. This time period was chosen to give the demand-side country time to react to the supply-side information. Forty-three responses were received from 18 countries. These consist of 33 completed questionnaires and 10 responses saying that the demand-side countries could find no information about the case. 



\section{Table of contents}

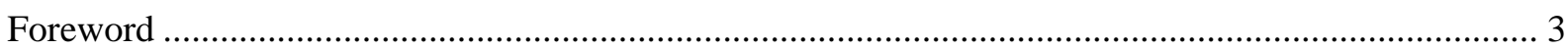

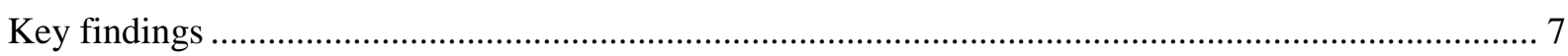

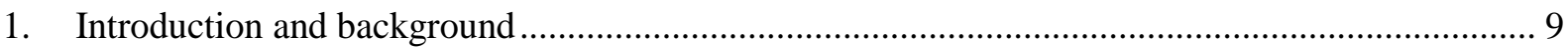

2. No assumption that perfect "flip side" symmetry would or should exist .................................... 10

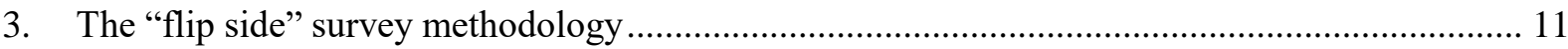

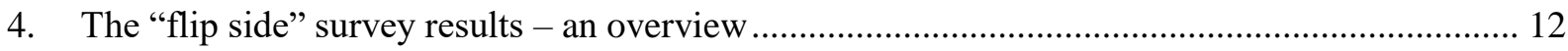

5. Demand-side case development - detection, investigation and sanctions.................................... 14

6. Other findings - Varied patterns of enforcement, largely consistent definitions of

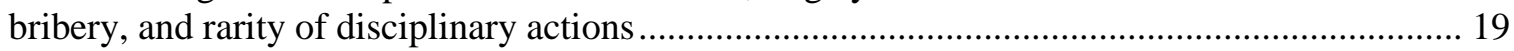

Annex. A more detailed description of the 'flip side' methodology ...................................................... 21 



\section{Key findings}

The main findings of the survey are as follows:

- Enforcement actions do take place on the demand side, but public officials are known to have been sanctioned in only one fifth of the 55 schemes covered by the survey. Public officials are subjected to law enforcement actions in a considerable number of cases. Of the 33 cases for which information was provided, 30 cases were investigated in the demand-side countries. Enforcement actions such as prosecutions were then undertaken in 20 of these cases and criminal sanctions are known to have been imposed on at least one public official in 11 cases. In addition, 11 actions are still pending at either the investigative or prosecutorial stages.

- The information flow between demand-side and supply-side enforcement authorities is often slow. The survey generated information about the dates when the demand-side countries became aware of the case for 28 cases. In 11 of the 28 cases, the demand-side country reports becoming aware of the case almost simultaneously (within one month) with the supply-side sanction being imposed. However, this information flow is sporadic. For the 5 cases where the demand-side country learned of the supply-side sanction after it was imposed, it took an average of 25 months for the demand-side country to become aware of the case. In 12 cases, the demand-side country was aware of the case before the supply-side sanction was imposed. In such cases, the average time between the demand-side country detecting the case and the supply-side jurisdiction imposing sanctions was 45 months.

- Exchange of information between demand-side and supply-side enforcement authorities was not a source of detection in this sample of cases. None of the demand-side countries detected the bribes involving their public officials through formal or informal communications with the supply-side enforcement authorities.

- The media plays a major role in international information flow. The media were the most important source of detection for the demand-side authorities, having been a source in 14 cases. Other sources of detection on the demand side were: reports by government institutions (4 cases); self-reporting by the offender ( 2 cases) and whistleblowers ( 2 cases).

- Sanctioning public officials for bribery poses the same enforcement challenges as sanctioning supply-side bribers. When public officials were not sanctioned, the survey responses often attribute it to standard problems encountered in criminal law enforcement: insufficient evidence (5 cases) and statute of limitations (4 cases). In one case no sanctions were imposed because the "effects of some offences on society were insignificant" and in another because key documents disappeared from the Ministry associated with the bribe. Finally, in 2 cases, sanctions were not imposed because the payments in question were not deemed to be illegal under the demand-side country's law. Finally, the machinery of justice appears to be quite slow in some countries. Although the cut-off date for inclusion 
of cases in the sample was 2013,5 of the cases are still pending at the stage of investigation and 6 at the stage of prosecution.

- Demand-side actions occurred mainly under criminal law; disciplinary actions under administrative law are reported to be rare. The survey also looks at disciplinary actions directed at public officials under administrative law. In 4 cases, public officials were targeted by non-criminal tax measures, some of which are still pending. In another case, two SOE employees were suspended from their positions, while, in another, a disciplinary procedure is described as pending and awaiting the outcome of criminal proceedings. This comparatively low number (relative to the number of actions taken under criminal law) may reflect more restrictive publication policies for disciplinary actions taken under administrative law or differential access to information on criminal versus administrative action for the individuals filling out the questionnaire. 


\section{Introduction and background}

Fighting corruption in all its forms is a top priority of the international community in general and of the OECD in particular. The OECD Working Group on Bribery (WGB) plays its part in this fight by helping its members to enact effective laws and to build enforcement capacity to combat the supply-side of foreign bribery. To have a globally effective overall enforcement system, however, both the supply-side participants (i.e. the bribers) and the demand-side participants (i.e. the public officials) of bribery transactions must face genuine risks of prosecution and sanctions.

If both sides of a bribery transaction face such risks, the overall deterrence effect of the global law enforcement system is enhanced. Public officials will be more afraid to ask for bribes and businesses will be more cautious when offering them. This is because, in theory, if the supply side of the bribe is detected, then the demand side of the bribe should soon be uncovered as well. Thus, taken together, effective enforcement on both sides of bribery transactions can lead to mutually reinforcing outcomes.

This study explores whether there is a "flip side" to enforcement actions that end with sanctions being imposed on a supply-side participant of a foreign bribery scheme - that is, were the public officials involved in the scheme also sanctioned or otherwise disciplined?

The Convention on Combating Bribery of Foreign Public Officials in International Business Transactions (the Anti-Bribery Convention) is the foremost global legal instrument for fighting the supply side of foreign bribery. ${ }^{1}$ The supply side of foreign bribery relates to what bribers do - it involves offering, promising or giving a bribe to a foreign public official to obtain an improper advantage in international business. ${ }^{2}$ In contrast, the demand side of foreign bribery refers to the offence committed by public officials who are bribed by foreign persons.

This paper explores empirically whether there are corresponding enforcement actions against the demand-side participants in a foreign bribery scheme when a concluded enforcement action resulted in sanctions being imposed on one or more of the scheme's supply-side participants. That is, if a company or an individual has been sanctioned for foreign bribery or a related offence in one jurisdiction, was the public official involved in the demand side of the offence also prosecuted or disciplined in that official's own jurisdiction? In this paper, this possibility - that there might be corresponding enforcement actions in supply-side and demand-side jurisdictions - is referred to as the "flip side" of enforcement actions or as "symmetry" in foreign bribery enforcement.

The study reports on the results of a survey of Parties to the Anti-Bribery Convention that gathers information on key patterns of law enforcement linking the supply and demand sides of foreign bribery. Notably it explores how, if at all, enforcement actions on the supply side of the bribery transaction are associated with enforcement or disciplinary actions for the public officials on the demand side of the transactions. It also looks at the results of such actions (pending, acquitted, or convicted?) and, where applicable, whether any sanctions were imposed (e.g. prison terms, fines, etc.).

In Section 2, the paper begins with a more detailed discussion of whether we should expect any relationship between demand-side and supply-side enforcement actions to

$1 \quad$ www.oecd.org/corruption/oecdantibriberyconvention.htm.

2 See Anti-Bribery Convention, article 1. 
exist in relation to foreign bribery. Section 3 explains the methodology of the study and provides details on the sample of 55 supply-side actions that ended in sanctions for an individual or a company. Section 4 provides an overview of the survey results (e.g. responses and non-responses), while Section 5 provides survey results on case development in the demand-side jurisdictions, from detection to prosecution and sanctioning. Section 6 discusses some other issues that arise from the survey. Finally, Section 7 proposes issues for discussion.

\section{No assumption that perfect "flip side" symmetry would or should exist}

While it is interesting to explore whether enforcement is taking place in both demand-side and supply-side jurisdictions, perfect symmetry between demand-side and supply-side actions in the area of foreign bribery is not expected to exist, nor should it. Even in a perfect world of completely effective law enforcement in all jurisdictions, a sanctioned case of supply-side foreign bribery might not be associated with a matching demand-side action for a variety of reasons:

- The facts of the case. For example, if a company is convicted for offering (but not giving) bribes, then it may be the case that the public official(s) in question did not accept the offer.

- Gaps in substantive law. Differences in substantive laws between supply-side and demand-side jurisdictions may create gaps in enforcement. For example, if the bribery offence is not described in the same terms between the demand-side and supply-side jurisdictions, it may be possible to prosecute in one jurisdiction and not in the other.

- Procedural hurdles. Such hurdles are potentially numerous. They include: different evidentiary standards across jurisdictions; different statutes of limitations; and delays in obtaining MLA when a crime occurs in another country. Such hurdles may prevent enforcement proceedings in the country that has, or should have, jurisdiction over the "flip side" of a foreign bribery transaction. Numerous examples of such procedural obstacles are found in the survey results.

Despite these caveats, one might expect - in an ideal world in which law enforcement for foreign bribery is proactive and effective in all jurisdictions - that if one jurisdiction obtained a conviction or otherwise sanctioned a supply-side participant in a foreign bribery scheme, there would be a relatively high rate of enforcement in the "flip side" jurisdiction(s). That is, one might not expect to find systematic action on the "flip side", but a rough symmetry should be apparent. This is because, for example, the information generated by concluded enforcement actions could provide a basis for action in the "flip side" jurisdiction(s). Under this scenario, the other jurisdiction would have, at the very least, a good starting point for launching its own investigation - one with a high probability of ending with a sanction.

Finally, the survey results show that, in practice, the geometry of foreign bribery enforcement is more complex than one of simple symmetry. In fact, in addition to finding that a supply-side case in one jurisdiction is often matched with demand-side case in another, the study also finds that supply-side bribers are pursued in the demand-side jurisdictions and, at times, demand-side bribe recipients are pursued in supply-side jurisdictions. Thus, both demand-side and supply-side actions take place in both jurisdictions, leading to a more complex pattern of law enforcement in which some of the more active countries target the full range of offenders that fall under their jurisdiction. 


\section{The "flip side" survey methodology}

The study uses a survey methodology based on questionnaires that were sent to selected Parties to the Anti-Bribery Convention (see Annex for a more detailed description of the methodology). The steps taken in developing the survey were:

- A sample of supply-side cases was established based on all known, publicly available supply-side cases that ended with sanctions for either foreign bribery or related crimes, such as books-and-records violations or conspiracy. ${ }^{3}$ The sample contains only cases in which supply-side sanctions were handed down between 2008 and 2013. This period was chosen in order to ensure that the demand-side jurisdictions had sufficient time to pursue the demand-side cases.

- A questionnaire was developed to gather background on the supply-side case and to pose questions about possible demand-side responses. ${ }^{4}$

- Fifty-five questionnaires were sent to the 20 demand-side countries in the sample and 43 responses were received from 18 Parties to the Anti-Bribery Convention. The questionnaires were sent out over the period May-June 2017 and responses were to be received by November 2017.

- The questionnaire responses were tabulated in order to generate the findings that are reported in Sections 5 and 6.

For this survey, the unit of analysis is a bribery scheme. A bribery scheme refers to one or more foreign bribery transactions involving a related set of facts. In many cases, more than one person or entity is prosecuted on both the demand and supply sides. Also, the schemes often involve bribes in several jurisdictions. Notably, 26 of the 55 questionnaires involve bribery schemes that took place in more than one demand-side jurisdiction.

In addition, the WGB decided to limit the questionnaire to cover only foreign bribery or related offences (e.g. books and records) involving Parties to the Anti-Bribery Convention on both the supply and demand sides. Thus, only cases involving Parties to the Anti-Bribery Convention on both sides are in the survey sample. This decision was made in deference to the political sensitivities of countries that are not Parties to the AntiBribery Convention and in order to facilitate the collection of information.

The plan for the survey was to provide as much information as possible on the supplyside cases to the demand-side countries in order to help them to track down information on criminal enforcement or other (administrative) disciplinary actions. This information generally came from the supply side enforcement authorities. In particular, 32 out of the 39 sanctions for supply-side bribery in the survey sample were concluded by the US Department of Justice (DOJ), the Securities and Exchange Commission (SEC) or both (sometimes in parallel with other law enforcement agencies). Their websites were the source of much of the information provided to the demand-side countries. The other 7 cases came from separate enforcement actions brought in Germany, Hungary, Italy, Korea, and the United Kingdom, plus two enforcement actions brought in Switzerland.

While the actual charge in the supply-side enforcement actions varies (e.g., books and records, conspiracy), money in fact changed hands in the vast majority of the cases covered by the completed questionnaires.

This questionnaire was discussed at the March 2017 meeting of the OECD Working Group on Bribery and then made available for comment and approval by written procedure. 
For the purposes of the "flip side" study, the fact that extensive information on these cases is posted on the US DOJ and/or SEC websites made it possible to provide details to the demand-side country on the circumstances of the bribery transactions. The survey sample itself was no doubt influenced by Parties' disclosure rules regarding information about supply-side cases. Different Parties to the Anti-Bribery Convention have different policies for disclosing such information. Additionally, the survey results may have been influenced by differing availabilities of information about criminal enforcement and administrative disciplinary actions.

\section{The "flip side" survey results - an overview}

\subsection{Responses and non-responses}

As noted above, of the 55 questionnaires sent to 20 Parties to the Anti-Bribery Convention, a total of 43 responses were received from 18 Parties. The 43 responses consisted of 33 questionnaires that were completed with details about the demand-side actions and of 10 responses stating that the demand-side country had no information about the case in their law enforcement archives.

One country attributed its difficulties in completing the questionnaire to the fact that due to personnel changes - the cut-off date for the survey sample (2013) made it difficult to retrieve the required information.

Thus, the overall response rate to the survey questionnaire is $78 \%$ - that is, the Secretariat received 43 completed questionnaires out of the 55 questionnaires sent to demand-side countries. The Secretariat did not receive a response of any kind for 12 questionnaires. It follows that the non-response rate for the survey is $22 \%$.

Because non-responses can introduce biases, they are an important consideration when interpreting survey results. For this study, for example, such a bias would occur if nonrespondents were systematically less likely to have investigated and prosecuted public officials than the respondent countries. In such a situation, survey results based only on completed questionnaires would produce upward-biased results for investigations, prosecutions and sanctions relative to the true situation. The reporting of survey results needs to consider this.

Figure 1. The "flip side" survey: How many responses and non-responses?

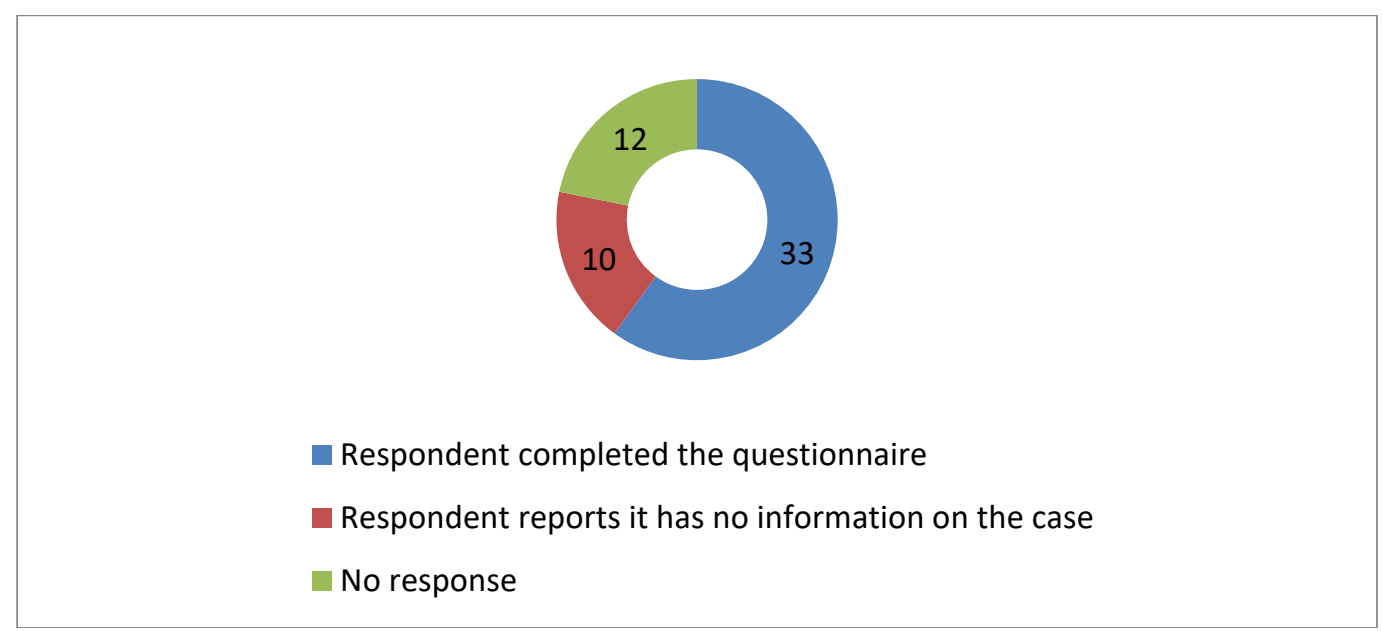

Source: OECD Working Group on Bribery “Flip side” Survey. Based on 55 questionnaires circulated. 


\subsection{Characteristics of the bribes covered in the completed questionnaires}

The 33 supply-side cases that form the basis of the survey results - that is, for which details of demand-side enforcement actions were provided - exhibit the following features:

- Most targeted sector - health care. The bribes often occur in the health-care sector (mainly, pharmaceuticals and medical devices). This sector accounts for 11 cases in the sample (Figure 2). The fact that such a large number of cases involve bribes paid to publicly employed doctors and hospital administrators could influence the results if demand-side jurisdictions have different propensities to prosecute health care professionals than other economic actors. The second most common sector was 'electrical power' (4 questionnaire responses), followed by 'oil and gas' and 'defence' ( 3 responses each). Two of the cases were in the 'telecommunications' sector, while 'other' sectors accounted 10 of the cases in the questionnaires. ${ }^{5}$

Figure 2. Sectors in which the bribes took place

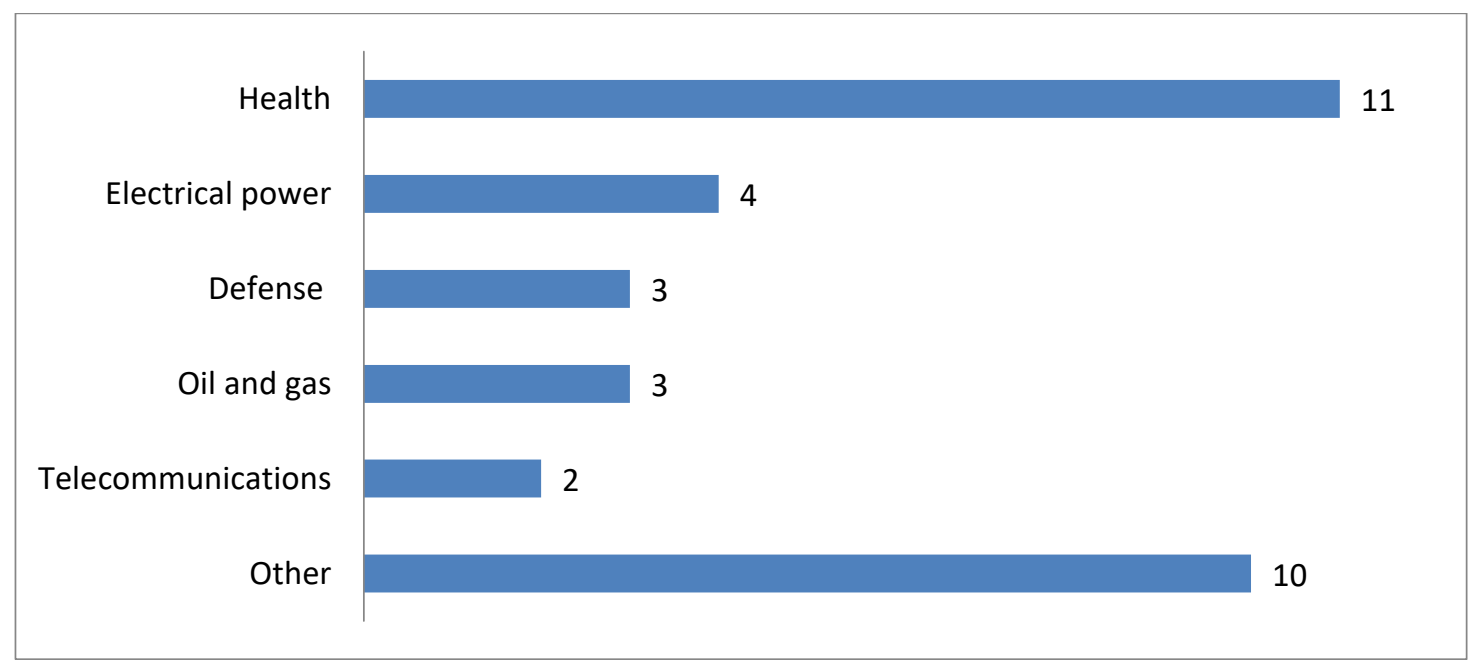

Source: OECD Working Group on Bribery "Flip side" Survey.

- Main motive - obtaining or retaining government business. Winning new business or preserving existing contracts in public procurement is, by far, the main motivation for the bribery transactions in the sample. Twenty-nine of the 33 bribery cases were motivated by the goal of "obtaining or retaining" government business. The dominance of this motivation in the present survey echoes the findings of the 2014 OECD Foreign Bribery Report. ${ }^{6}$ In 7 cases, other motives were present, including: to expedite customs, circumvent export controls or to otherwise lower the costs of international trade (4 cases) and to influence tax authorities and to settle disputes over cost overruns.

5 The "other" category includes manufacturing (e.g. apparel, transport vehicles, marine hose and metal packaging) as well as diverse business services.

6 www.oecd.org/corruption/oecd-foreign-bribery-report-9789264226616-en.htm 
- Roles of public officials bribed. The bribed officials occupied a variety of roles and functions within the public sector. These include: hospital administrators/purchasers (14 cases), SOE employees ( 7 cases), custom officials (4 cases), armed forces/defence sector operatives (3 cases) and municipal officials ( 2 cases).

\section{Demand-side case development - detection, investigation and sanctions}

The 33 cases in the survey sample provide information about how demand-side authorities detected the alleged offence and how they used this information (Figure xx). In 30 of the 33 cases investigations of demand-side offences were initiated. Twenty of these investigations then led to enforcement actions such as prosecution. In 11 cases, criminal sanctions were imposed on one or more public officials. Details about the development of these demand-side cases are provided in the sections below.

Figure 3. Demand-side case development: investigation, prosecution and sanctions

(out of 33 cases where details of case development are known and out of a total of 55 cases covered by the survey)

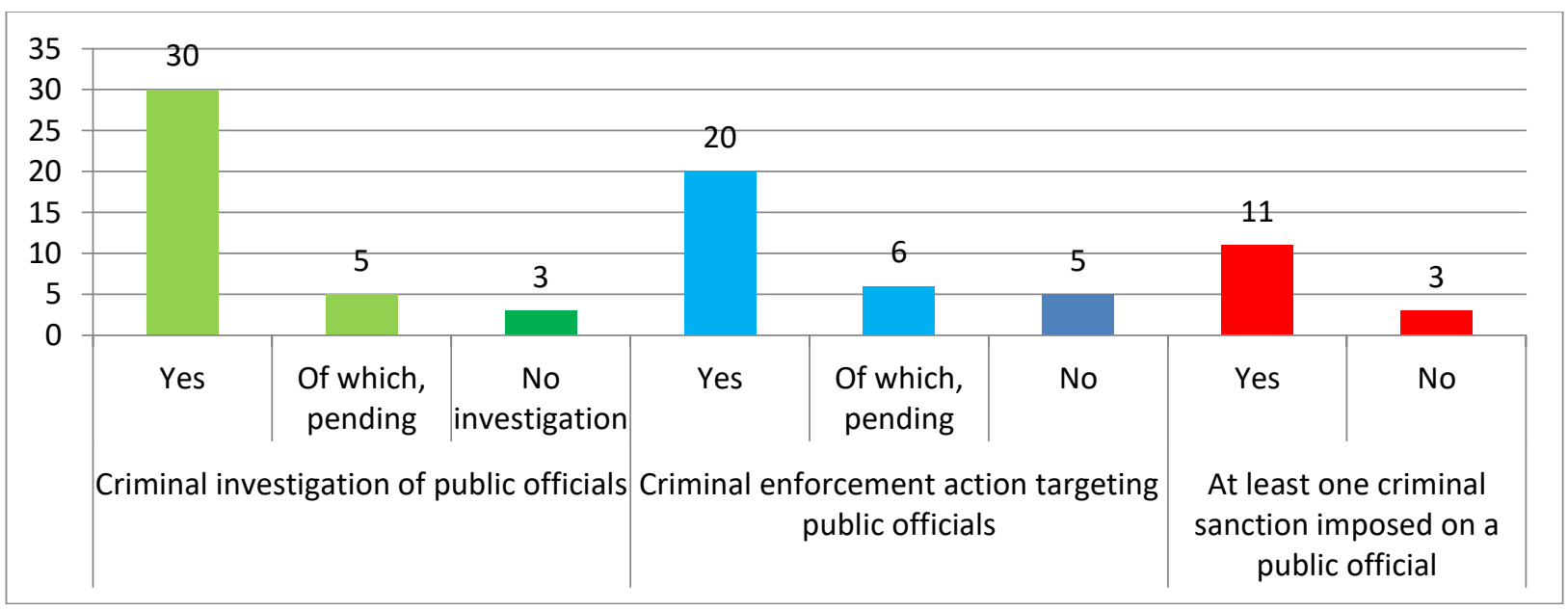

Source: OECD Working Group on Bribery "Flip side" Survey.

\subsection{Detection - Various sources, but little direct information exchange between enforcement authorities}

Twenty-eight questionnaire responses provided information on how the demand-side countries became aware of their respective cases. Of the 28 cases, the responses on sources of detection show a heavy reliance on the media (14 cases). Demand-side authorities' own detection efforts were a source in 8 cases. In addition, reports by government institutions were mentioned in 4 cases, including the social security administration, electrical power commissions and tax authorities. Self-reporting by the offender was a source in 2 cases and whistleblowers in 2 cases. In one case, a labour union's report was a source. ${ }^{7}$

7 Some responses indicated more than one source of detection. 
It is noteworthy that, although the survey questionnaire explicitly poses the question, none of the responses indicate that the demand-side country learned of the supply-side enforcement action directly from the supply-side country that imposed the sanction. Nevertheless, in at least one case, mutual legal assistance was sought by the demand-side country at the investigations stage.

The media appears to play the role of intermediary in the information flow between the demand-side and supply-side jurisdictions. Indeed demand-side media seem to cover the supply-side cases extensively. In order to understand the role of the media better, a web search was conducted on the 12 cases in the "flip side" sample that correspond to two Latin American demand-side countries, ${ }^{8}$ each of which has 6 cases in the sample. The purpose of the web search was to gage the extent of the demand side country's media coverage of the supply-side cases involving bribes given to their public officials. This web search shows that the two countries' national media (including newspapers, the business press and specialised online publications for the medical profession) covered the cases involving bribery of their public officials in great detail. All 12 cases received extensive coverage in the two countries' media, including in the general press, the business press and specialise media (e.g. a medical journal). The articles often refer to the findings of enforcement agencies in the supply-side countries (mainly, US DOJ and SEC).

Thus, when it is available, official information on supply-side cases appears to be closely followed by the media, at least in these two demand-side countries. For Parties to the Anti-Bribery Convention with more restrictive rules governing publication of information on completed cases, it is clear that media channels for transmitting information about cases to the demand-side jurisdictions would not exist. When the supply-side enforcing country restricts public information about enforcement actions, such information can only pass from supply-side to demand-side jurisdictions through formal or informal international cooperation.

The fact that demand-side countries reported little detection through direct contacts with the supply-side countries' enforcement authorities is difficult to explain. Perhaps international legal cooperation was less developed during the sample period (2008-2013 for completion of the supply-side case). It is also surprising in view of the extensive detail about most of these supply-side cases that is posted on the DOJ and SEC websites via press releases and legal documents. Such information is readily available to anyone who speaks English and has access to the internet.

\subsection{Direction and speed of information flow between jurisdictions}

The timely flow of information about cases across jurisdictions is a key requirement for effective international law enforcement. This section sheds light about how much time it took for both the demand- and supply-side countries to become aware of the bribe scheme. For the supply-side cases, the only available information about timing is the date of the conclusion of the supply-side case (date of detection is not available on the supply side). On the demand side, the questionnaire asks countries when they became aware of the bribery transaction.

The Secretariat received 28 responses to this question, making it possible to compare how much time it took for the information about these cases to become available in both

8 The Secretariat focused on Spanish-speaking countries because the Secretariat was able to review Spanish-language media coverage of the cases. 
jurisdictions ${ }^{9}$ (Table 1). In 11 of these cases, the demand-side country became aware of the case almost simultaneously (within a month) with the conclusion of the case in the supply-side country.

The other 17 cases fell into the following two scenarios:

- Scenario 1 - Supply-side sanctions imposed first, then demand-side country detects. In 5 cases, the supply-side sanction was imposed before the demand-side country became aware of the case. In these 5 cases, the demand-side country learned of the case an average of 24 months after the sanction was imposed. The maximum time was 48 months for the demand-side country to learn of the case after the supply-side sanction was imposed.

- Scenario 2 - Demand-side country detects case before supply-side sanctions are imposed. In 12 cases, the demand-side country was aware of the scheme before the supply-side county imposed sanctions. In such cases, the average time between the demand-side country detecting the case and the supply side imposing sanctions was 45 months and the maximum time period was 121 months. ${ }^{10}$

Table 1. Length of time for information to flow between demand-side and supply-side jurisdictions

\begin{tabular}{lcc}
\hline & $\begin{array}{c}\text { Scenario 1. Cases where the } \\
\text { supply-side sanction was } \\
\text { imposed before demand-side } \\
\text { became aware }\end{array}$ & $\begin{array}{c}\text { Scenario 2. Cases where the } \\
\text { demand-side became aware } \\
\text { of the case before supply- } \\
\text { side sanction was imposed }\end{array}$ \\
\cline { 2 - 3 } $\begin{array}{l}\text { Number of cases } \\
\text { Average time period between } \\
\text { imposition of supply side sanctions } \\
\text { and detection on demand side }\end{array}$ & 24 months & 12 \\
$\begin{array}{l}\text { Maximum time period between } \\
\text { supply side sanction and demand- } \\
\text { side detection }\end{array}$ & 48 months \\
Minimum length of time & \multicolumn{2}{c}{$\begin{array}{c}121 \text { months } \\
\text { In } 11 \text { cases, awareness was almost simultaneous (less than a } \\
\text { month difference between demand- side awareness and } \\
\text { supply-side imposition of sanctions) }\end{array}$} \\
\hline
\end{tabular}

Source: OECD Anti-Bribery Convention "Flip side" Survey.

$9 \quad$ For the supply-side country, the only information available on timing related to the date when the cases were concluded. Thus, the information available for the demand-side country is time of detection, while the information available for the supply-side country is time of conclusion.

This case with the maximum time period involved a charitable contribution to a foundation in Eastern Europe. This contribution was investigated in the demand-side jurisdiction and was found not to be a bribe. On the supply side, this payment was part of a broader case involving bribe transactions in the health care sector in multiple countries. 


\subsection{Investigations and enforcement actions (e.g. prosecutions)}

Demand-side investigations were undertaken in 30 of the 33 completed questionnaires (Figure 3). All 30 investigations concerned 'accepting bribes'. Other offences at issue include:

- Soliciting a bribe: 3 cases;

- Aiding, abetting or conspiring to engage in bribery offence: 4 cases;

- Embezzlement or misappropriation of public property: 2 cases;

- Money laundering: 5 cases;

- Trading in influence: 2 cases;

- Other offences: 5 cases (e.g. fraud and breach of trust; illicit enrichment; filing false tax returns; and document forgery in order to gain material benefit).

Twenty of these investigations led to enforcement actions (e.g. prosecutions) targeting one or more public officials.

In 11 of the 33 questionnaire responses giving details of the enforcement actions (33\%), the demand-side jurisdiction reported that the case was still pending, either at the stage of investigation ( 5 cases) or prosecution (6 cases).

\subsection{Number and types of sanctions}

Of the 30 demand-side cases that were investigated, 11 cases resulted in criminal sanctions being imposed on at least one public official (Figure 3). Thus, 37\% of the 30 investigations resulted in at least one criminal sanction.

Sanctions rates can also be calculated based on the number of foreign bribery offences that are known to have been committed (they are 'known' because they were the subject of supply-side sanctions.). However, in doing so, some consideration must be given to the meaning of the non-responses to the questionnaire and of the responses indicating that no information on the case is available in the demand-side jurisdiction. A conservative approach would be to assume that all of the non-responses and 'no information' responses indicate that the case was not pursued in the demand-side country.

Accordingly, three sets of alternative sanctions rates are calculated with the following results:

- $33 \%$ of the 33 cases for which there are completed questionnaires resulted in criminal sanctions on at least one public official;

- $26 \%$ for the 43 questionnaires which were completed or for which the country reported having 'no information' involved sanctions; and

- $20 \%$ for the total set of 55 cases (including the 10 "no information" responses and the 12 non-responses). 
For the 11 bribery schemes that resulted in criminal sanctions on at least one public official, the sanctions consisted of prison sentences, fines, and/or confiscation or equivalent coercive measure (Figure 4). Details are as follows (note that some cases involved multiple sanctions):

- Terms of imprisonment: 10 cases;

- Suspended term of imprisonment: 4 cases;

- Fines: 6 cases;

- Confiscation, disgorgement or forfeiture: 8 cases;

- Debarment or prohibition of activity: 4 cases.

Figure 4. Criminal sanctions on public officials

(out of 33 known cases, from a total of 55 cases covered by the survey questionnaire)

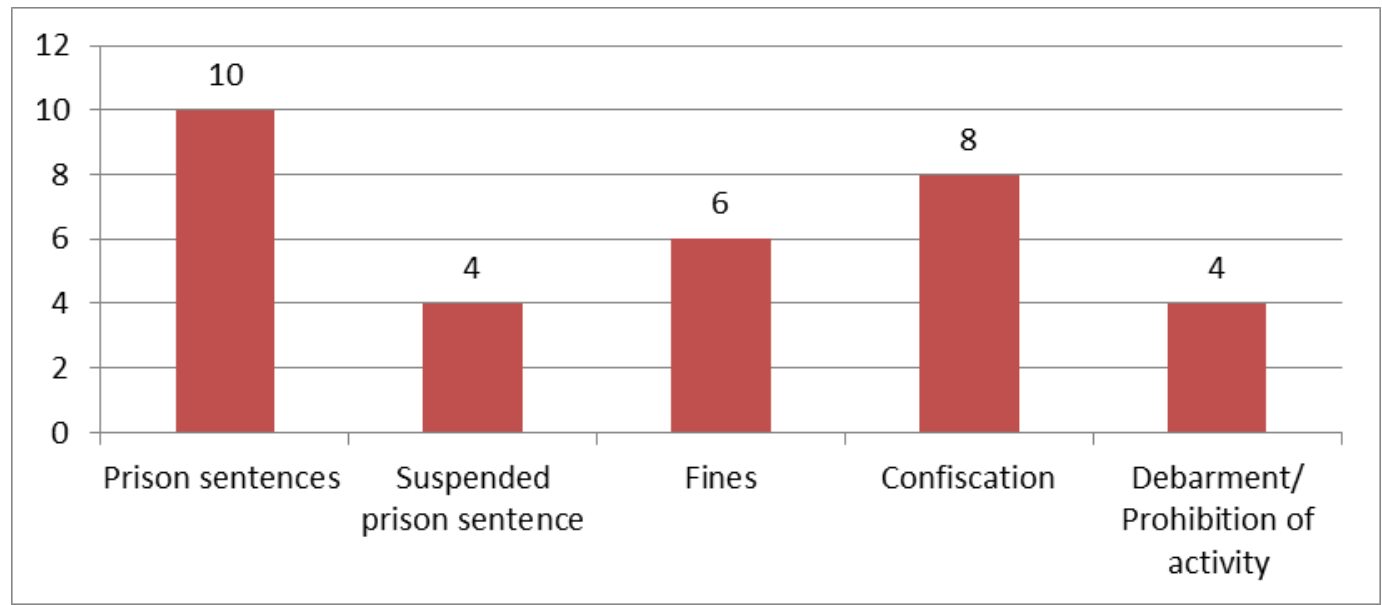

Source: OECD Working Group on Bribery “Flip side” Survey.

\subsection{Relatively high numbers of pending cases in some countries}

The survey results also point to what appears to be a slow process of completing cases in some demand-side countries. Investigations are still pending in 5 cases. This means that the country is still investigating these cases, on average a little over 5 years after it became aware of the case. Six of another country's responses state that the enforcement action (e.g. prosecution) is still pending. For these 6 cases, an average of 6.5 years has elapsed from the time of detection. 


\subsection{Reasons for not prosecuting}

The demand-side countries that did not prosecute public officials cited the following reasons:

- No prosecution due to insufficient evidence: 5 cases.

- Statute of limitation: 4 cases.

- Investigation revealed that the payments made were not criminal under domestic law: 2 cases.

- Lack of resources: 1 case.

- No prosecution because the "effects of some offences on society were insignificant": 1 case.

- Disappearance of key documents from the Ministry associated with the bribe: 1 case.

\section{Other findings - Varied patterns of enforcement, largely consistent definitions of bribery, and rarity of disciplinary actions}

\subsection{The enforcement pattern is more complicated than simple, matching actions in the demand-side and supply-side countries}

The questionnaire responses reveal that the enforcement actions taken by the countries in the survey sample often involved both demand-side and supply-side responses. Specifically, 11 of the demand-side countries undertook enforcement actions on both the supply and demand sides of the bribery transaction, while, in a few cases, the supply-side country also prosecuted demand-side actors.

Examples of this variable geometry of enforcement include:

- Natural persons on both the demand side and the supply side were sanctioned in the demand-side country. Several natural persons who gave bribes and who were nationals of the demand-side country were investigated and prosecuted in parallel with the public officials.

- Law on the liability of legal persons was not in place, so no capacity to prosecute local subsidiary. One demand-side country notes that it would have prosecuted the legal person on the supply side of the bribe, but could not because its law on legal person liability has not entered into force at the time the criminal offence took place.

- Demand-side country invites supply-side briber to its jurisdiction. The demand-side government invited the individual on the supply-side of the bribe to its jurisdiction (ostensibly to settle a commercial dispute) and then arrested him. This person had already been sanctioned in his home country for the same bribe.

Thus, the questionnaire responses point more to a variable geometry of enforcement actions, rather than to simple symmetry between demand- and supply-side jurisdictions. This may indicate that an international enforcement framework is emerging in which various jurisdictions use their legal authority to pursue the parties to bribery for which they have what might be thought of as a "comparative legal advantage". 


\subsection{Supply- and demand-side countries largely agree on the legal definition of bribery}

In only 2 cases - or about $6 \%$ of the 33 completed questionnaires - did the demandjurisdiction conclude that, factually, no demand-side crime was committed in their jurisdictions for an act that was sanctioned as foreign bribery in a supply-side jurisdiction.

In one of these, the questionnaire response merely states without explanation that there was no contravention of domestic bribery law by public officials. The second case involves a charitable contribution made for re-furbishing a castle in eastern Europe - the 'pet project' of a regional health care official. The demand-side jurisdiction investigated and found no evidence that the contributions "were associated with performing any public function" by the director of the health fund. In contrast, in the supply-side legal documents, the same payment is identified as part of a larger, international bribery scheme that was subject to sanctions.

\subsection{Non-criminal disciplinary actions against public officials are rare}

The questionnaires describe fewer administrative actions against public officials than criminal actions. Specifically, six cases in the sample were accompanied by non-criminal disciplinary actions. In 4 cases, public officials were targeted by non-criminal tax measures, some of which are still pending. In another case, two SOE employees were suspended from their positions. In still another case, a disciplinary procedure is described as still pending and awaiting the outcome of the criminal proceedings. No information about disciplinary actions under administrative law is provided in any of the other questionnaire responses.

The reasons for the relative scarcity of disciplinary actions under administrative law in the survey responses are not clear. It may be due to different information availabilities regarding criminal actions versus disciplinary actions in the public sector - rules on information disclosure may be different or the individuals filling out the questionnaires may have had better access to information on criminal proceedings than on administrative proceedings.

Taken at face value, however, these results would seem to indicate that anti-corruption activity in demand-side countries is very much a matter for criminal law and that disciplinary actions arising out of public sector management practices are relatively less important. Moreover, the problems identified in the questionnaire in effectively sanctioning public officials who may have received bribes are classic criminal law enforcement problems - statute of limitations, meeting evidentiary standards, and the significant time required for successful case development in criminal law (detection, prosecution and resolution). 


\section{Annex. A more detailed description of the 'flip side' methodology}

The study's methodology involves the following steps:

Establishing a sample of completed cases and bribery schemes. A sample was identified of publicly available, concluded enforcement actions in which one Party to the Anti-Bribery Convention convicted or otherwise sanctioned a participant on the supplyside of a foreign bribery scheme that involved an official from at least one other Party to the Anti-Bribery Convention on the demand side. These concluded cases are associated with various bribe schemes (there might be several actions for one scheme or several schemes for one action). This sample is provided consists of bribery schemes for which enforcement actions have been identified from various OECD sources (mainly the OECD Foreign Bribery Report database) as well as external sources (e.g. the Trace Compendium and the Shearman \& Sterling FCPA database). The sample is further limited to enforcement actions that were concluded between 2008 and 2013 in order to account for any lag time that might arise between the initial prosecution by one Party to the AntiBribery Convention and proceedings launched by the "flip side" jurisdiction.

Design of the questionnaire for the "flip side" of each bribery scheme. The OECD Secretariat designed a draft questionnaire for "flip side" jurisdictions to be filled out for each scheme in the sample of concluded supply-side foreign bribery cases. To study the demand-side actions arising out of successful WGB supply-side enforcement cases, the questionnaire contained two parts. Part A covers background information on the supplyside case to be filled out by the Secretariat to the maximum extent possible. This includes, where available, links to sources providing background information on the bribery schemes in English. Part B is for demand-side countries whose public officials may have been bribed based on the information generated by a successful supply-side action in another Party to the Anti-Bribery Convention.

Distributing the questionnaires. Under the procedure, the questionnaires were sent out in mid-2017 to the demand-side countries.

Tabulating the results. The responses to the questionnaire have been tabulated in an Excel spreadsheet. Tabulations include the number of non-respondents and the responses to the various questions posed in Part B of the "flip side" questionnaire.

Reporting the results. Aggregate values for these data items are reported for the entire sample of cases. In addition, facts relating to the enforcement actions has been collected, organised and presented: what percentage of demand-side cases were dropped because they were time barred? What were the outcomes for cases in the sample that involved low-level versus high-level public officials?

Potential weaknesses in the methodology. These include: 1.differences among jurisdictions in the public availability of information about court decisions and investigations; 2. differences among jurisdictions in obtaining information about decisions and investigations (e.g. due to language barriers when accessing information from foreign bribery cases or the absence of remote accessing capabilities); 3 . differences in administrative structure (e.g. centralised versus federalised systems), which may bear on access to information. 
www.oecd.org/corruption<smiles>[Co]=[GeH2]</smiles> 